\title{
Utility of Fine Needle Aspiration Cytology of Lymph nodes
}

\author{
${ }^{1}$ Dr. Ripunjaya Mohanty, ${ }^{2}$ Dr. Anne Wilkinson, \\ ${ }^{I}$ Senior Resident, ${ }^{2}$ Associate Professor \\ Department Of Pathology, NKP Salve Institute Of Medical Sciences and Research Centre, Digdoh Hills, \\ Hingna, Nagpur MAHARASHTRA 440019, INDIA
}

\begin{abstract}
Background: The incidence of lymphadenopathy appears to be increasing, especially among young adults all over the world. Their frequent involvement in regional and systemic diseases and their easy accessibility make the cytomorphological study of lymph nodes a permanent activity of pathologists. Inflammatory and immune reactions are the most frequent causes of lymph node enlargement and are self limiting in majority of cases. Lymphoid tissue undergoes reactive changes to a wide variety of antigenic stimuli. Tuberculosis, which is common in India, can also be diagnosed by cytology of affected lymph nodes. Lymph nodes are also affected as a result of primary neoplasm of the node itself and from metastasis of malignant neoplasm from regional and distant organs. With the advent of FNAC, most of the inflammatory, reactive and neoplastic conditions can be diagnosed without biopsy. It has the advantage that it can be done safely, rapidly and cheaply with minimal trauma at an outpatient setup or at the bedside.

Material and Methods: This study was conducted at our institute which caters to patients belonging mostly to the lower socioeconomic group, after IEC [Institute Ethics Committee] approval. Written informed consent was obtained from all patients. It included 355 patients with lymphadenopathies at various sites. Acellular aspirates were excluded from the study. FNAC was conducted with the help of a 22 guage disposable needle attached to a 20cc syringe. Smears were fixed in $95 \%$ ethyl alcohol and stained with Haematoxylin and Eosin as well as Papanicolaou stains. Leishman stain was done on air dried smears. The cases suspected as Lymphoma were confirmed by biopsy or referred for Immunohistochemistry. The results expressed as percentage were tabulated.
\end{abstract}

Results: Maximum numbers of patients were diagnosed with Reactive Lymphadenopathy 122/355 (34.36\%), followed by Chronic Granulomatous Inflammation 72/355(20.28 \%),Metastatic Lymphadenopathy 65/355(18.30 $\%)$, Acute Suppurative Lymphadenopathy 40/355 (11.26\%), Tuberculous Lymphadenopathy 28/355 (7.88\%), Primary neoplasm 14/355 (3.94\%), Non Specific Lymphadenopathy 10/355 (2.81 \%) and Sinus Histiocytosis $4 / 355(1.12 \%)$. Histopathological correlation was available only in 36/355 cases. The correlation was correct in 32/36 cases [88.88\%], making the sensitivity of the procedure $72.2 \%$. In case of malignancies the histopathological correlation was $100 \%$.

Conclusion: FNAC is a safe, simple \& inexpensive definite diagnostic procedure to render a prompt diagnosis for lymph node enlargements, especially in lymph node aspirates where biopsies are not done routinely.

Key Words: Fine needle aspiration cytology, lymph nodes

\section{Introduction}

Medicine is an ever-changing science and the past few decades have witnessed dramatic advances in every sphere. Despite rapid advances and the advent of newer methods of diagnostic imaging, an important determinant of patient management rests on tissue diagnosis. Lymph nodes are among the commonly aspirated organs for diagnostic purposes. Since the flourishing of the technique in the 1950s, the sphere of FNAC has come a long way in conjunction with sophisticated CT, MRI and USG guided procedures to become an important diagnostic tool. Nevertheless, the few cells that are obtained from the lesion are often found sufficient to make the diagnosis, and biopsies are usually done only in inconclusive cases or sometimes in the case of malignancies in the lymph node.

\section{Aims And Objectives}

1. To categorize various lesions of lymph nodes by fine needle aspiration cytology.

2. To correlate the cytological findings with the histopathological findings in cases where lymph node biopsy is done.

3. To find out the number of cases where FNAC of the lymph node picked up an unsuspected malignancy (primary or secondary). 


\section{Materials And Methods}

In the present study, all clinically diagnosed cases of lymphadenopathies reporting at the cytology section for FNAC, over a period of three years, from June 2009 to May 2012 were included. Most of the patients were referred from surgery, pediatrics, medicine, dermatology, and ENT departments. This study was conducted at our institute after IEC [Institute Ethics Committee] approval. Written informed consent was obtained from all patients.

A brief clinical history followed by a meticulous, physical examination was done and the findings were noted. These cases were subjected to fine needle aspiration cytology and later followed up. Acellular aspirates were excluded from the study. Cytological findings were noted in all the cases. In some of the cases where the biopsy was done, their histopathology was correlated with the cytological diagnosis. In those cases where lymphoma and leukemic infiltration of lymph nodes were suspected on cytology, bone marrow aspiration and other necessary hematological investigations were done.

\section{Results}

Table 1 shows diagnosis of aspirated lesions, with age and sex distribution. Reactive lymphadenopathy was the most frequent diagnosis making up 34.36\% [122/355] of the cases. Maximum cases were seen in the third decade, with males 182/355 (51.3\%) being slightly more affected than females 173/355 (48.7\%).

Table 2 shows sites and side of lymph nodes aspirated. The cervical group was the most common site of lymph nodes aspirated [236/355].

Table 3 shows distribution according to types of malignant lymph node lesions aspirated.

Metastatic tumors [65/79] were more common than the lymphomas [14/79].

Table 4 shows that $36.7 \%$ [29/79] of the malignancies diagnosed on cytology were clinically unsuspected.

Table 5 shows the cytology correlation with histopathology in 36 cases

Table 1: Diagnosis of aspirated lesions with age and sex distribution

\begin{tabular}{|c|c|c|c|c|c|c|c|c|c|c|c|c|c|c|c|}
\hline Cytological diagnosis & Sex & $\begin{array}{l}0- \\
10\end{array}$ & $\begin{array}{l}11- \\
20\end{array}$ & $\begin{array}{l}\text { 21- } \\
30\end{array}$ & $\begin{array}{l}31- \\
40\end{array}$ & $\begin{array}{l}41- \\
50\end{array}$ & $\begin{array}{l}\text { 51- } \\
60\end{array}$ & $\begin{array}{l}\text { 61- } \\
70\end{array}$ & $\begin{array}{l}\text { 71- } \\
80\end{array}$ & $\begin{array}{l}\text { 81- } \\
90\end{array}$ & $\begin{array}{l}91- \\
100\end{array}$ & $\begin{array}{l}\text { 101- } \\
110\end{array}$ & Total & $\begin{array}{l}\text { Grand } \\
\text { Total }\end{array}$ & $\%$ \\
\hline \multirow{2}{*}{$\begin{array}{l}\text { Acute suppurative } \\
\text { lymphadenopathy }\end{array}$} & $\mathrm{M}$ & 5 & 2 & 3 & 3 & 5 & 2 & 1 & - & - & - & - & 21 & \multirow{2}{*}{40} & 11.26 \\
\hline & $\bar{F}$ & 2 & 5 & 5 & 3 & 3 & 1 & - & - & - & - & - & 19 & & \\
\hline \multirow{2}{*}{$\begin{array}{l}\text { Chronic } \\
\text { granulomatous } \\
\text { lymphadenopathy }\end{array}$} & $\mathrm{M}$ & 3 & 6 & 8 & 6 & 5 & 4 & - & - & - & - & - & 32 & \multirow{2}{*}{72} & 20.28 \\
\hline & F & 2 & 7 & 16 & 8 & 4 & 1 & 2 & - & - & - & - & 40 & & \\
\hline \multirow{2}{*}{$\begin{array}{l}\text { Tuberculous } \\
\text { lymphadenopathy }\end{array}$} & $\mathrm{M}$ & - & 1 & 3 & 5 & 2 & 1 & 1 & - & - & - & - & 13 & \multirow[t]{2}{*}{28} & 7.88 \\
\hline & $\mathrm{F}$ & - & 5 & 5 & 2 & 3 & - & - & - & - & - & - & 15 & & \\
\hline \multirow{2}{*}{$\begin{array}{l}\text { Reactive } \\
\text { lymphadenopathy }\end{array}$} & $\mathrm{M}$ & 20 & 12 & 12 & 11 & 6 & - & 3 & 2 & - & - & - & 66 & \multirow[t]{2}{*}{122} & 34.36 \\
\hline & $\mathrm{F}$ & 10 & 12 & 15 & 8 & 8 & 3 & - & - & - & - & - & 56 & & \\
\hline \multirow{2}{*}{$\begin{array}{l}\text { Non } \\
\text { lymphadenopathy }\end{array}$} & $\mathrm{M}$ & 1 & 1 & 1 & 1 & - & - & - & - & - & - & - & 4 & \multirow[t]{2}{*}{10} & 2.81 \\
\hline & $\mathrm{F}$ & 2 & 1 & - & 1 & 1 & 1 & - & - & - & - & - & 6 & & \\
\hline \multirow[t]{2}{*}{ Sinus histiocytosis } & $\mathrm{M}$ & - & - & 1 & - & - & - & - & - & - & - & - & 1 & \multirow{2}{*}{4} & 1.12 \\
\hline & F & - & - & 1 & - & - & 1 & - & 1 & - & - & - & 3 & & \\
\hline \multirow{5}{*}{$\begin{array}{l}\text { Primary malignant } \\
\text { lymphadenopathy } \\
\text { - Non Hodgkin's } \\
\text { lymphoma }\end{array}$} & & & & & & & & & & & & & & \multirow{3}{*}{13} & \\
\hline & M & - & 1 & - & 2 & 1 & 1 & 1 & 1 & - & - & - & 7 & & 3.66 \\
\hline & $\bar{F}$ & 1 & - & 2 & - & 1 & 2 & - & - & - & - & - & 6 & & \\
\hline & $\mathrm{M}$ & - & - & - & - & - & 1 & - & - & - & - & - & 1 & \multirow[t]{2}{*}{1} & 0.28 \\
\hline & F & - & - & - & - & - & - & - & - & - & - & - & - & & \\
\hline \multirow{2}{*}{$\begin{array}{l}\text { Metastatic } \\
\text { lymphadenopathy }\end{array}$} & $\mathrm{M}$ & - & - & 1 & 4 & 3 & 14 & 9 & 4 & - & - & 1 & 36 & \multirow{2}{*}{65} & 18.30 \\
\hline & $\mathrm{F}$ & - & 1 & 1 & 5 & 8 & 5 & 9 & - & - & - & - & 29 & & \\
\hline Total & & - & - & - & - & - & - & - & - & - & - & - & - & 355 & \\
\hline
\end{tabular}


Table2: Sites and Side of Lymph Nodes Aspirated

\begin{tabular}{|l|l|l|l|l|}
\hline Sr. No. & Site & Right & Left & Total \\
\hline I & Cervical lymph node & 131 & 105 & 236 \\
\hline II & Submental lymph node & - & - & 10 \\
\hline III & Supraclavicular lymph node & 7 & 13 & 20 \\
\hline IV & Infraclavicular lymph node & 1 & - & 1 \\
\hline V & Occipital lymph node & - & - & 1 \\
\hline VI & Axillary lymph node & 30 & 31 & 61 \\
\hline VII & Inguinal lymph node & 16 & 10 & 26 \\
\hline & - & - & - & 355 \\
\hline
\end{tabular}

Table 3: Distribution according to site and type of malignant lymph node lesions.

\begin{tabular}{|c|c|c|c|c|c|c|}
\hline Cytological diagnosis & $\begin{array}{l}\text { Cervical } \\
\text { LN }\end{array}$ & $\begin{array}{l}\text { Supra- } \\
\text { clavicular } \\
\text { LN }\end{array}$ & $\begin{array}{l}\text { Infra- } \\
\text { clavicular } \\
\text { LN }\end{array}$ & $\begin{array}{l}\text { Axillary } \\
\text { LN }\end{array}$ & $\begin{array}{l}\text { Inguinal } \\
\text { LN }\end{array}$ & Total \\
\hline \multicolumn{7}{|l|}{ A) Metastatic Lesions } \\
\hline Squamous cell carcinoma & 21 & 2 & - & 1 & - & 24 \\
\hline Ductal malignancy & - & 1 & 1 & 8 & - & 10 \\
\hline $\begin{array}{l}\text { Poorly differentiated epithelial } \\
\text { malignancy }\end{array}$ & 12 & 1 & - & 2 & 5 & 20 \\
\hline Adenocarcinoma & 4 & 2 & - & 2 & 1 & 9 \\
\hline Malignant Melanoma & - & - & - & 1 & - & 1 \\
\hline Leukaemic Infiltrate & 1 & - & - & - & - & 1 \\
\hline \multicolumn{7}{|l|}{ B) Primary Lesions } \\
\hline Non Hodgkin's Lymphoma & 7 & 2 & - & 2 & 2 & 13 \\
\hline Hodgkin's Lymphoma & 1 & - & - & - & - & 1 \\
\hline Total & 46 & 8 & 1 & 16 & 8 & 79 \\
\hline
\end{tabular}

Table 4: Table Showing Clinically Suspected and Unsuspected Lymph Node Malignancies

\begin{tabular}{|l|l|l|}
\hline Cytological diagnosis & $\begin{array}{l}\text { Clinically } \\
\text { suspected }\end{array}$ & $\begin{array}{l}\text { Clinically } \\
\text { unsuspected }\end{array}$ \\
\hline Metastatic lesions & & \\
\hline Squamous cell carcinoma & 20 & 4 \\
\hline Ductal malignancy & 10 & - \\
\hline Poorly differentiated epithelial malignancy & 8 & 12 \\
\hline Adenocarcinoma & 5 & 4 \\
\hline Malignant melanoma & - & 1 \\
\hline Leukaemic infiltrate & - & 1 \\
\hline Primary Lesions & & \\
\hline Non- Hodgkin's Lymphoma & 7 & 6 \\
\hline Hodgkin's Lymphoma & 1 & - \\
\hline Total & $\mathbf{5 0}$ & $\mathbf{2 9}$ \\
& $(\mathbf{6 3 . 3 \% )}$ & $(\mathbf{3 6 . 7 \% )}$ \\
\hline
\end{tabular}

Table 5: Cytology correlation with histopathology $\quad($ Total $=36)$

\begin{tabular}{|l|l|l|l|l|}
\hline Cytological diagnosis & Total & $\begin{array}{l}\text { HP } \\
\text { correlated }\end{array}$ & $\begin{array}{l}\text { HP } \\
\text { correlated }\end{array}$ & $\begin{array}{l}\text { Percentage of accuracy } \\
\text { of } \\
\text { histopathology } \\
\text { correlation }\end{array}$ \\
\hline $\begin{array}{l}\text { Acute Suppurative } \\
\text { lymphadenopathy }\end{array}$ & 7 & 4 & $\begin{array}{l}2-\text { Tuberculosis } \\
1-\text { Well differentiated } \\
\text { squamous cell carcinoma }\end{array}$ & $57 \%$ \\
\hline Reactive lymphadenopathy & 5 & 5 & - & $100 \%$ \\
\hline Sinus histiocytosis & 1 & 1 & - & $100 \%$ \\
\hline $\begin{array}{l}\text { Chronic Granulomatous } \\
\text { lymphadenopathy suggestive } \\
\text { of Tuberculosis }\end{array}$ & 6 & 6 & - & $100 \%$ \\
\hline $\begin{array}{l}\text { Chronic Inflammation } \\
\text { Primary Malignant }\end{array}$ & 3 & 3 & - & 0 \\
\hline lymphadenopathy (NHL) & 1 & - & - & $100 \%$ \\
\hline Metastatic lymphadenopathy & 13 & 13 & - Angioimmunoblastic & $0 \%$ \\
\hline Total & 36 & 32 & 4 & $100 \%$ \\
\hline
\end{tabular}

Sensitivity $=72.2 \%$ 


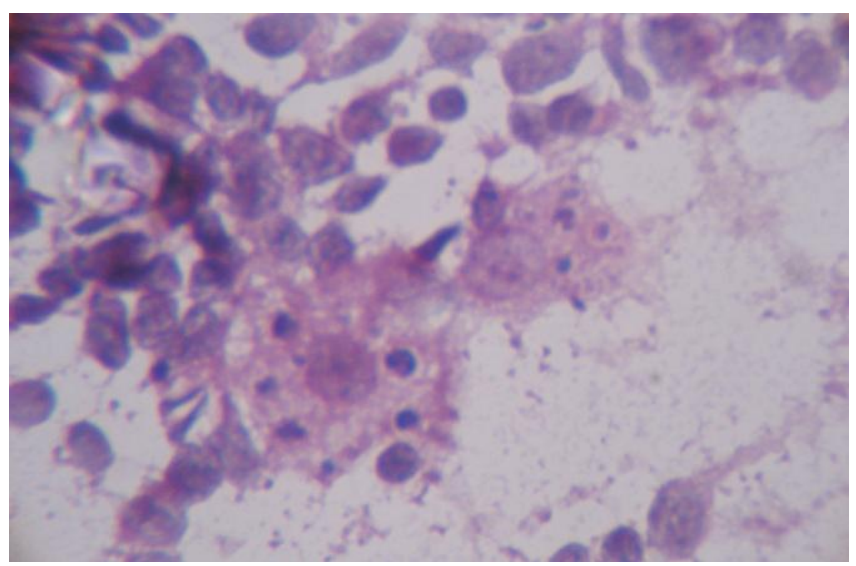

Figure 1. Photomicrograph of smear of reactive lymph node hyperplasia showing tingible body macrophages. (Haematoxylin and Eosin stain x 400)

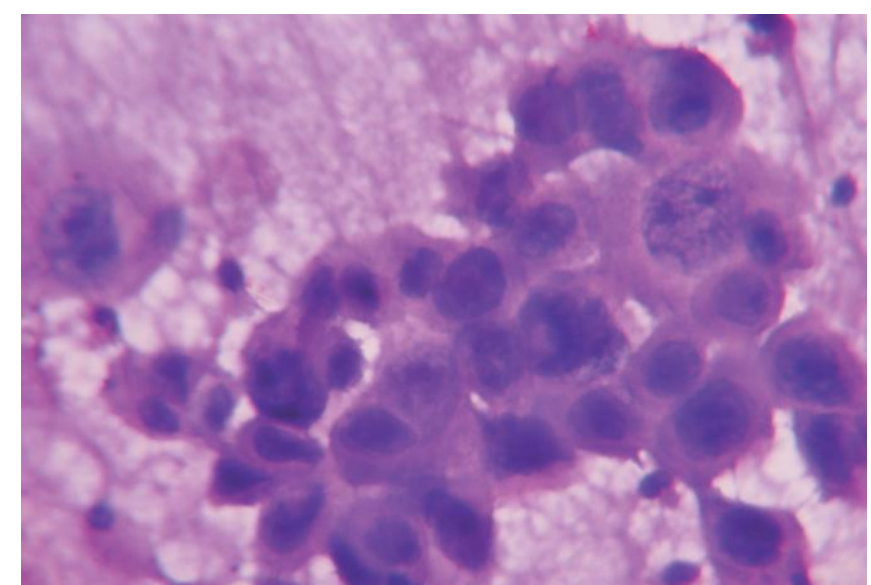

Figure 2. Photomicrograph of smear of lymph node aspirate showing a group of malignant squamous cells with large hyperchromatic nuclei.

( Haematoxylin and Eosin $\mathrm{x}$ 400)

\section{Discussion}

The lymphatic system is one of the most important systems in the body through which diseases may not only be cleared away, but also spread from one part of the body to another. Lymphadenopathy is a commonly encountered clinical condition requiring prompt and accurate diagnosis so that a proper treatment protocol can be started as early as possible. FNAC is a completely safe, quick and inexpensive method for quick diagnosis of lymphadenopathy, reducing need of surgical biopsy. In the present study we performed FNAC on 355 patients of lymphadenopathy over a period of 3 years. The pattern of lesions varied from non-neoplastic lesions like tuberculous lymphadenopathy, reactive lymphadenopathy, acute suppurative lymphadenopathy, granulomatous lymphadenopathy, sinus histiocytosis and non-specific lymphadenopathy, to neoplastic lesions like metastatic lymphadenopathy and Lymphomas.

In our study, reactive lymphadenopathy was observed to be the most frequent diagnosis with 122/355 cases $(34.36 \%)$. It was also the most frequent diagnosis in other studies and its incidence has been seen to range from $18.9 \%$ to $42 \%{ }^{[1,2,3,4]}$ All the 5 biopsies of reactive lymphadenopathy received, correlated with the cytological diagnosis $(100 \%)$.

The second most frequent diagnosis in this study was observed to be chronic granulomatous inflammation with $72 / 355$ cases $(20.28 \%)$. The incidence of granulomatous inflammation was observed to vary from $9.2 \%$ to $25.45 \%$ in other studies. ${ }^{[3,4]} 6$ biopsies reported on cytology as chronic granulomatous lymphadenopathy suggestive of tuberculosis revealed tuberculosis in all the biopsies, which shows $100 \%$ correlation.

Tuberculosis lymphadenopathy diagnosed by cytology alone occurred in 28/355 (7.8\%) of our cases. Other previous studies showed this condition varying from $28 \%$ to $52 \%{ }^{[2,3,5,6]}$ There were no biopsies done in any of our cases probably because the clinicians were convinced with our cytological diagnosis, correlating with their clinical diagnosis. In another study conducted by Surase et al who diagnosed 800 cases of tuberculosis on cytology, only 4 had biopsy done, which correlated $100 \% .{ }^{[7]}$ 
Acute Suppurative Lymphadenopathy was observed to be a frequent occurrence with 40/355 cases [11.26\%] in our study. 7 cases of cytologically diagnosed Acute Suppurative Lymphadenapathy had $100 \%$ biopsy correlation in 4 cases. In the remaining 3 biopsies, 1 was diagnosed as well differentiated squamous cell carcinoma while the other 2 revealed tuberculosis. A study on tuberculous lymphadenitis done by Sarwar et al, ${ }^{[8]}$ found only necrosis without epithelioid granuloma in $35 \%$ cases. Surase et $\mathrm{al}^{[7]}$ in their study also found one of the cytological patterns of tubercular lymphadenopathy to be only of necrotic material without epithelioid cells, or giant cells. In such cases Zeihl- Nielson "es stain should be done to demonstrate Acid Fast Bacilli. Both our cases of suppurative Lymphadenopathy were negative for Acid Fast Bacilli. Hence, the diagnosis of tuberculosis could not be done in these 2 cases by cytology alone. Squamous Cell Carcinoma is known to be associated with necrosis. Finding only necrotic material on cytology without the evidence of malignant cells was noted in $2 \%$ cases, in a study conducted by Kiran Alam et al ${ }^{[9]}$ and $4.1 \%$ cases of the study by Bhagwan et $\mathrm{al}^{[10]}$.

The present study also comprised 10/355 (2.8\%) cases diagnosed as non specific lymphadenopathy on cytology. This correlated with the study of Haque and Talukdar ${ }^{[11]}$ who found the incidence to be $2.63 \%$ of all lymph nodes aspirated. There was one case which we misdiagnosed as chronic non specific lymphadenitis on cytology. This was a $35 \mathrm{yr}$ old male with a single right cervical tender lymph node of $1.5 \times 1.5 \mathrm{cms}$ size of one month duration, which was subsequently biopsied and diagnosed as angioimmunoblastic lymphadenopathy. This condition was possibly not diagnosed by us on cytology as plasma cells and immunoblasts are seen in both conditions.

We diagnosed 79/355 [22.25\%] neoplastic lesions in the lymph nodes by FNAC, of which more cases of metastatic involvement $65 / 79$ [82\%] rather than lymphoma 14/79 [18\%] were seen. This was similar to other Indian studies. ${ }^{[2,9]}$ Other studies have found the incidence of neoplastic involvement to vary from $10.1 \%$ to $47.8 \% .^{[3,5,6,12]}$ A Brazilian FNAC study on lymph nodes diagnosed 79.4\% metastasis and $14.2 \%$ lymphomas. $^{[13]}$ A study conducted in Egypt has reported more involvement by lymphomas $(80.3 \%)$ rather than metastatic diseases $(19.7 \%){ }^{[14]}$ Histopathological correlation [16/79 cases] was $100 \%$ in all our cases of metastatic and primary malignancies of lymph nodes. Since most of our patients belonged to the lower socio economic group, we only referred cases of lymphoma for immunohistochemistry when the patient could afford it.

In our study the cervical group was the most common to be involved by metastasis (38/65 cases $58.4 \%$ ) and the primary was most often from the oral cavity, which was similar to other studies, ${ }^{[3,15]}$ with squamous cell carcinoma being the most common histological type. ${ }^{[9,10,15,16]}$ Rates for oral cavity, pharynx, oesophagus and male larynx are highest in India, probably due to the use of multiple tobacco products. ${ }^{[17]}$ A full history, radiological investigations and immuno-histochemistry in selected cases may help to locate the primary site. Specialised investigations like a combination of lymphosyntigraphy and USG guided FNAC's of sentinel lymph nodes in the head and neck area have been found to be good in picking up metastasis in clinically undetectable lymph nodes. ${ }^{[15]}$ In our study $29 / 79$ cases $(36.7 \%)$ of malignant involvement of lymph nodes were not clinically suspected. Hence FNAC plays a major role in diagnosing these cases.

Although we had a very low number of $36 / 355$ cases $(10.1 \%)$ with histopathological correlation, we could diagnose reactive lymphadenopathy, sinus histiocytosis, chronic granulomatous lesion suggestive of tuberculosis and malignant lesions with $100 \%$ accuracy. The low number of biopsies was probably due to the clinicians' satisfaction with the cytological diagnosis. Thus FNAC of the lymph nodes can be used as an effective and simple diagnostic tool for lymph node lesions.

\section{Summary And Conclusions}

FNAC is an important diagnostic tool for diagnosing benign as well as malignant lesions. It is a safe, simple and inexpensive definite diagnostic procedure to render a prompt diagnosis, especially in lymph node aspirates, where biopsies are not done commonly. It can also pick up unsuspected malignancies. Our study also demonstrated the fact that lymph node biopsies are done mostly in the case of primary and sometimes metastatic lesions. The limitations faced are with necrotic lymphadenopathy, where if the clinician is unsatisfied with the cytological diagnosis, a lymph node biopsy is helpful to make a correct diagnosis.

\section{Bibliography}

[1]. Kochhar K, Patel B, Shah M. Pattern of Lymphadenopathy on Fine Needle Aspiration Cytology of Superficial Lymph Nodes (A Study of 150 Cases). JARBS 2012; 4: 288-292.

[2]. Khajuria R, Goswami KC, Singh K, Dubey VK. Pattern of Lymphadenopathy on Fine Needle Aspiration cytology in Jammu. JK Science Journal of Medical Education and Research 2006; 8:157-159.

[3]. Hirachand S, Lakhey M, Akhter J, Thapa B. Evaluation of Fine Needle Aspiration Cytology of Lymph Nodes in Kathmandu Medical College Teaching Hospital. Kathmandu University Medical Journal 2009; 7:139-142.

[4]. Adhikari P, Sinha BK, Baskota DK. Comparison of fine needle aspiration cytology and histopathology in diagnosing cervical lymphadenopathies. AMJ 2011; 4: 97-99.

[5]. Paul PC, Goswami BK, Chakrabarti S, Giri A, Pramanik R. Fine Needle Aspiration Cytology of Lymph Nodes - An institutional study of 1448 cases over a five year period. Journal of Cytology 2004; 21:187-90. 
[6]. Ahmad T, Naeem M, Ahmad S, Samad A, Nasir A. Fine Needle Aspiration Cytology (FNAC) and Neck swellings in the surgical department. Journal of Ayub Medical College Abbottabad 2008; 20:30.

[7]. Surase S, Sisodia SM, Shedge R. Role of Fine Needle Apiration Cytology in Tuberculous Lymphadenitis. Bombay Hospital Journal 2009; Special Issue: 17-19.

[8]. Sarwar A, Haque A, Aftab S, Mustafa M, Moatasim A, Siddique S et al. Spectrum of Morphological Changes in Tuberculous Lymphadenitis. International Journal of Pathology 2004; 2:85-89.

[9]. Alam K, Khan AH, Siddiqui FA, Jain A, Haider N. Fine Needle Aspiration Cytology (FNAC), a handy tool for metastatic lymphadenopathy. The Internet Journal of Pathology 2010;10. Available from: http://www.ispub.com/journal/the_internet_journal_of_pathology

[10]. Bhagwan IN, Kane SV, Chinoy RF. Cytologic Evaluation of the Enlarged Neck Node: FNAC Utility in Metastatic Neck Disease. The Internet Journal of Pathology 2007; 6. Available from: http://www.ispub.com/journal/the_internet_journal_of_pathology

[11]. Haque MA, Talukder SI: Evaluation of fine needle aspiration cytology (FNAC) of lymphnodes in Mymensingh. Mymensingh Med J 2003; 12:33-5.

[12]. Ghartimagar D, Ghosh A, Ranabhat S, Shrestha MK, Narasimhan R, Talwar OP. Utility of fine needle aspiration cytology in metastatic lymph nodes. Journal of Pathology of Nepal 2011; 1: 92-95.

[13]. Martin MR, Santos GC. Fine Needle Aspiration Cytology in the diagnosis of superficial lymphadenopathy: a 5 year Brazilian experience. Diagn Cytopathol 2006; 34:130-134.

[14]. Hafez NH, Tahoun NS. Reliability of fine needle aspiration cytology (FNAC) as a diagnostic tool in cases of cervical lymphadenopathy. Journal of the Egyptian National Cancer Institute 2011; 23: 105-114

[15]. Hoftr S, Muhle C, Brenner W, Sprenger E, Maune S. Fine-Needle Aspiration Cytology of the Sentinel Lymph Node in Head and Neck Cancer. J Nucl Med 2002; 43:1585-90.

[16]. Mitra S, Ray S, Mitra PK. Fine needle aspiration cytology of supraclavicular lymph nodes: our experience over a three year period. J Cytol 2011; 28: 108-110.

[17]. Loya AC, Pragya AK, Arora A, Sundaram UC, Rao IS, Uppin SG et al. Lymph node metastasis of soft tissue tumours: A Cytomorphologic study. Acta Cytol 2007; 51: 153-160. 